\title{
Long term evolution of caustic induced esophagitis: A descriptive 20-years cohort.
}

\author{
Chaouch Mohamed Ali 1,2*, Nacef Karim 1,2, Ben Khalifa Mohamed 1,2, Ghannouchi \\ Mossab 1,2, Chaouch Asma 1,2, Boudokhane Moez 1,2.
}

1: Department of general surgery, Tahar Sfar
Hospital, Mahdia, Tunisia
2: College of medicine Monastir Tunisia
* Corresponding author
Correspondence to:
docmedalichaouch@gmail.com
Publication data:
Submitted: November 15, 2019
Accepted: January 26, 2020
Online: March 15, 2020

This article was subject to full peer-review.

This is an open access article distributed under the terms of the Creative Commons Attribution Non-Commercial License 4.0 (CCBY-NC) allowing to share and adapt.

Share: copy and redistribute the material in any medium or format.

Adapt: remix, transform, and build upon the licensed material.

the work provided must be properly cited and cannot be used for commercial purpose.

\section{Abstract:}

Introduction:

Corrosive esophagitis following caustic agent ingestion remains a significant medical and social concern in Tunisia. Secondary stricture is the most challenging complication. The aim of this study is to determine the incidence of caustic esophageal injuries and to highlight the characteristics of the management.

Methods:

Over a 20 years period, we conducted a retrospective and descriptive study about 164 consecutive patients presented to our department following ingestion of caustic agents.

Results:

The mean age was 26 years (16-87) with a gender ratio of 0.2 . The ingestion was accidental in $58 \%$ of cases and as a suicidal attempt in $42 \%$. Bleach largely dominates ingested solutions in $78.3 \%$ of cases. The delay of the consultation was less than 12 hours in $98.4 \%$ of cases. We noticed gravity signs in eight patients. Lesions in Esophagoscopy were recorded in 62 patients (37.8\%). The esophageal injury assessed as grade I in 36 patients, grade IIa limited lesions in 10 patients, grade IIa extensive in 8 patients, grade IIb in 5 patients and grade III in 3 patients. During the follow-up, 26 patients $(41.9 \%)$ had a second assessment during the secondary stage, only 4 patients (2.4\%) presented esophageal strictures. Three patients underwent coloplasty for esophageal replacement.

Conclusion:

During a 20-year period, 164 cases of caustic ingestion were reported. Constituted esophagitis injuries were noted in $37.8 \%$ and strictures in $6.45 \%$ of all cases.

Key words: Incidence, caustic agents, stricture, esophagus, Tunisia 
Long term evolution of caustic induced esophagitis: A descriptive 20-years cohort.

\section{Introduction}

Ingestion of corrosive caustic substances remains a public health issue. Caustic injury is more common in children due to accidental ingestion [1]. In adults, ingestion occurs mostly for a suicidal purpose that increase the gravity. These corrosive substances may cause serious injuries in the esophagus. Prognosis is essentially related either to early septic complications or late sequelae [2]. The most challenging early complication is the esophagus necrosis. The main purpose of the initial assessment is to detect features predicting the transmural necrosis [3]. The major secondary consequence is esophageal strictures. Surgery may be required at any stage of the evolution. Hereby, we report our experience in caustic esophagitis management.

\section{Patients and methods}

We conducted a 20 years retrospective cohort study of consecutive patients admitted to our Surgical Department following caustic agent ingestion (1999-2018). We recorded the age, gender, the ingested substance's nature and the circumstances of ingestion. The data of the first assessment including clinical, biological, radiological and endoscopic findings was collected for each patient. A descriptive analysis of the second and third patient's assessments details was performed. The outcome of the endoscopic and surgical procedures was noted.

\section{Results}

Systematic eso-gastroscopy was done for all the patients. esophageal injury was found in 62 patients (37.8\%). Clinical features of these patients were reported in Table 1. Female predominance with sex ratio of 0.2 was noted. Accidental ingestion presented in $58 \%$ and suicidal attempt in $42 \%$. The most common reasons were school failure and family conflicts.

Table 1: Clinical features of patients with an esophageal caustic injury.

\begin{tabular}{|lc|}
\hline Variable & $\mathbf{n}$ \\
\hline Age (years) & \\
Mean & \\
range & 26 \\
& $16-87$ \\
Gender ratio & 0.2 \\
M & 12 \\
F & 50 \\
Suicide attempt (\%) & \\
Accident (\%) & $26(42)$ \\
& $36(58)$ \\
\hline
\end{tabular}

Bleach was the most common ingested solutions (78.3\%). The ingested substances were liquid in all cases. The consultation delay was < 12 hours in $98.4 \%$ of cases. All the patients did not present symptoms suggesting digestive perforation (abdominal contracture or cervical subcutaneous emphysema). We noticed agitation in seven patients and haematemesis in one patient. Esophagoscopy was systematically performed with no iatrogenic complications. The endoscopy was performed within less than 12 hours in 35 patients, between 12 and 24 hours in 105 patients and more than 24 hours in 24 patients. During endoscopy, Esophageal lesions were recorded in 62 patients (table 2,3).

Table 2: Endoscopic classification of caustic injuries (modified Di Costanzo [8])

\begin{tabular}{|c|c|}
\hline Grade & Features \\
\hline Grade 0 & Normal \\
\hline Grade I & Superficial mucosal edema and erythema \\
\hline Grade IIa limited & Superficial erosions, non-confluent, number $<5$ \\
\hline Grade IIa extensive & Confluent circular ulcerations, extensive, number $>5$ \\
\hline Grade IIb & Circumferential confluent ulcerations, hemorrhage, punctiform necrosis \\
\hline Grade III & Extensive necrosis and important haemorrhage \\
\hline Grade IV & Total mucosal carbonization, perforation \\
\hline
\end{tabular}

Grade 0 and grade1 patients were monitored for 24 hours and discharged with proton pump inhibitor for one week. Grade IIa limited lesions were recorded in 10 patients $(16.1 \%)$. They were allowed to have oral diet after 48 hours. Grade IIa extensive was found in eight patients $(12.9 \%)$, grade IIb in five patients $(8 \%)$ and grade III in three patients $(4.8 \%)$. These patients were kept NPO with exclusive parenteral nutrition.

The intravenous intake was performed during 12 to 14 days for eight patients (grade IIa) and for 20 to 25 days for the eight patients (grade IIb or III). No patients had grade IV endoscopic lesions.

During the follow-up, 26 patients (41.9\%) underwent an assessment during the second stage. Only four patients $(6.45 \%)$ developed esophageal strictures. Surgical repair of these delayed associated lesions was required in three cases. These patients underwent esophageal replacement. No treatment-related death was recorded in our in our study. 
Long term evolution of caustic induced esophagitis: A descriptive 20-years cohort.

Table 3: Distribution of caustic substances according to their nature and esophageal injury

\begin{tabular}{|c|c|c|c|c|c|c|c|c|}
\hline \multicolumn{2}{|l|}{ Caustic agent } & \multirow[t]{2}{*}{ n (\%) } & \multirow[t]{2}{*}{ Esophageal injury } & \multicolumn{5}{|c|}{ Endoscopic findings } \\
\hline & & & & $\mathbf{G}_{\mathbf{I}}$ & $\mathbf{G}_{\text {III L }}$ & $\mathbf{G}_{\text {IIa E }}$ & $\mathbf{G}_{\text {IIb }}$ & $\mathbf{G}_{\text {III }}$ \\
\hline Oxidant & Bleach & $127(78.3)$ & $42(33 \%)$ & 28 & 6 & 4 & 3 & 1 \\
\hline & $\mathrm{H}_{2} \mathrm{O}_{2}$ & 1 & 1 & 1 & & & & \\
\hline Alkaline & Sodium bicarbonate & $14(8.6)$ & $13(92.8 \%)$ & 5 & 3 & 2 & 1 & 2 \\
\hline Acidic & Hydrocholeretic acid & 6 & $4(66 \%)$ & 2 & 1 & 1 & & \\
\hline Others & & $14(8.6)$ & $2(14.2 \%)$ & 1 & 1 & & & \\
\hline
\end{tabular}

Table 4: evolution and management

\begin{tabular}{|c|c|c|c|c|c|c|c|}
\hline Case & $\begin{array}{l}\text { Stricture diagnosis } \\
\text { (months) }\end{array}$ & $\begin{array}{l}\text { Endoscopy } \\
\text { findings }\end{array}$ & mucosa & Gswallow findings & Endoscopic treatment & Procedure & Post-operative \\
\hline $1^{\text {st }}$ & 9 & $\begin{array}{l}\text { Stricture of the } \\
\text { upper } \\
\text { esophageal } \\
\text { sphincter }\end{array}$ & $\begin{array}{l}\text { Adhesions of the } \\
\text { hypopharynx }\end{array}$ & $\begin{array}{l}\text { Interrupted examination due } \\
\text { to inhalation }\end{array}$ & Four endoscopic release & $\begin{array}{l}\text { Coloplasty was } \\
\text { performed after } 20 \\
\text { months }\end{array}$ & $\begin{array}{l}\text { Hypersalivation and } \\
\text { total dysphasia evoking } \\
\text { anastomotic stricture } \\
\text { managed with } \\
\text { endoscopic dilatation }\end{array}$ \\
\hline $2^{\text {nd }}$ & 6 & $\begin{array}{l}\text { Punctiform } \\
\text { impenetrable } \\
\text { stricture at } 26 \mathrm{~cm} \\
\text { from dental } \\
\text { arches }\end{array}$ & Inflammatory & $\begin{array}{l}\text { Stricture of the esophageal } \\
\text { lower third of } 15 \mathrm{~cm} \text { length }\end{array}$ & & $\begin{array}{l}\text { Peristaltic transverse } \\
\text { coloplasty }\end{array}$ & Uneventful \\
\hline $3^{d}$ & 8 & $\begin{array}{l}\text { Stricture of the } \\
\text { upper esophageal } \\
\text { sphincter }\end{array}$ & Normal & $\begin{array}{l}\text { Multiple stricture of the } \\
\text { esophagus }\end{array}$ & $\begin{array}{l}\text { Multiple endoscopic } \\
\text { dilatation }\end{array}$ & $\begin{array}{l}\text { Patient has refused } \\
\text { surgery }\end{array}$ & \\
\hline
\end{tabular}

\begin{tabular}{|c|c|c|c|c|c|c|}
\hline $4^{\text {th }}$ & 5 & $\begin{array}{l}\text { Tight stricture at } \\
27 \mathrm{~cm} \text { from } \\
\text { dental arches }\end{array}$ & Inflammatory & $\begin{array}{l}\text { Stricture of the esophagal } \\
\text { middle third at } 27 \mathrm{~cm} \text { from } \\
\text { dental arches }\end{array}$ & $\begin{array}{l}\text { Eso-coloplasty with } \\
\text { antral resection }\end{array}$ & $\begin{array}{l}\text { Systemic candidiasis } 7 \\
\text { months after surgery }\end{array}$ \\
\hline
\end{tabular}

\section{Discussion}

Caustic ingestion is a life-threatening incident. It may lead to esophageal perforation [4]. Survivors to initial fatal complications may have esophageal stricture. This is more frequent in children than adults. In our study, the mean age was 26 years. The majority of adult caustic esophagitis studies showed female predominance. However, pediatric studies showed male predominance $[5,6]$. This ingestion is mostly accidental for children and voluntary for suicidal intent for adults [7]. One hundred sixteen out of our patients presented a favorable outcome with no sequelae (97\%). Di Constanzo [8] and Andreoni [9] respectively reported that the healing rates without sequelae were $80 \%$ and $84 \%$ of patients. This can be explained by the large predominance of diluted bleach over other ingested agents.
This was concordant with the previous report with domestic caustic substances which cause severe problems [10]. Few studies had focused on predictive factors for esophageal stricture after caustic ingestion. High BMI, suicidal intent, initial severe clinical presentation, hemostasis troubles, endoscopic grade and some agents' characteristics (extreme pH values, alkaline agents, volume and concentration) were the most reported factors correlated with a high risk of esophageal stricture. Major esophageal injury series in adults demonstrated that alkaline substances are more harmful than acids. Acids cause coagulation necrosis while the alkaline agents combine with tissue proteins and lead to vessels thrombosis that decrease the blood supply of already 
damaged organs. This may be also explained also by the highes viscosity and a longer contact time with the esophagus mucosi. $[11,12]$. In our study, ingestion of alkaline agents was almost constantly associated with esophageal injuries and leaded to 3 of the four diagnosed stricture cases. Clinical features depend on the type of the substance, amount, physical form and delay of consultation [13]. The laboratory studies are more useful in monitoring and guiding patient management than in predicting esophageal injury. Esophagoscopy is the most fundamental examination of the initial assessment and the cornerstone of management of caustic injuries. It provides an appraisal of topography, extension and significance of lesions [14]. The best time for endoscopy is between the 3rd and 24th hours after ingestion. It must be performed whenever caustic ingestion is certain or strongly suspected as soon as hemodynamic and psychiatric stabilization have been achieved. Endoscopic classification is important for the management and prognosis assessment. The endoscopic degree of esophageal injury is an accurate predictive factor of systemic complications and mortality $[15,16]$. Currently, Computed tomography (CT) has become widely indicated in caustic injuries specially in severe clinical presentation [17]. CT scan is effective in the early evaluation of caustic damage. It offers more detailed evaluation than endoscopy about the esophageal transmural lesions and the extent of necrosis [18]. Regarding secondary complications, the incidence of esophageal stricture varies widely. A rate of $5 \%$ to $75 \%$ was reported. This can be due to an unclear definition of stricture in many reports, heterogeneity of corrosive substances and variable delay to stricture diagnosis. In our study, the stricture rate was $2.4 \%$. This low incidence can be explained by the large predominance of diluted bleach ingestion (78.3\%). Tight esophageal stricture, multifocal or extensive and irregular lesions, requires esophagoplasty [19]. This was the case in three patients in our study after the failure of the endoscopic option. Reconstructive surgery is indicated firsthand in patients of multifocal stricture, in children, in case of the tracheoesophageal fistula with recurrent respiratory infection [20]. Our limitations in this work were the retrospective description and some missing follow up data.

\section{Conclusions}

Caustic ingestions remain a life-threatening accident. Fortunately, most ingestions are benign, especially in case of accidental ingestion. The main purpose of clinical and biological assessments is to detect gravity features predicting transmural necrosis. A digestive stricture is the most challenging secondary complication. Currently, there is no preventive treatment for esophageal stricture following corrosive ingestion in the adult. The predictive factors remain a subject of research and debate.

\section{Conflict of interest: none}

\section{References}

[1] Bandyopadhyay N, Fass R, Yamasaki T, Hemond C. Esophageal Injury. In: Pocket Handbook of Esophageal Disorders. Springer; 2019. p. 133-41.

[2] French D, Sundaresan S. Caustic Esophageal Injury. In: Shackelford's Surgery of the Alimentary Tract, 2 Volume Set. Elsevier; 2019. p. 515-25.

[3] Bouabdellah S, Hannache K, Benmati A, Kellil M, Bouhroum A, Roula D. Epidemiologic analysis of digestive corrosive burns in adults. J. Afr. Hépatol. Gastroentéro. $2012 ; 6$ :264-71.

[4] Tohda G, Sugawa C, Gayer C, Chino A, McGuire TW, Lucas CE. Clinical evaluation and management of caustic injury in the upper gastrointestinal tract in 95 adult patients in an urban medical center. Surgical endoscopy. 2008; 22:1119-25.

[5] Keskin E, Okur H, Koltuksuz U, Zorludemir Ü, Olcay I. The effect of steroid treatment on corrosive esophageal burns in children. Eur.J.Pediatr. Surg.1991; 1:335-38.

[6] Sarfati E, Gossot D, Assens P, Celerier M. Management of caustic ingestion in adults. Br.J.Surg . 1987; 74:146-48.

[7] Doğan Y, Erkan T, Çokuğraş FÇ, Kutlu T. Caustic gastroesophageal lesions in childhood: an analysis of 473 cases. Clinical pediatrics. 2006 ; 45 :435-38.

[8] Di Costanzo J, Noirclerc M, Jouglard J, Escoffier JM, Cano N, Martin J, et al. New therapeutic approach to corrosive burns of the upper gastrointestinal tract. Gut. $1980 ; 21: 370-75$.

[9] Andreoni B, Trivellini G, Marini A, Biffi R, Castelli L, Farina ML, et al. Traitement d'urgence des lésions duodénales graves dues à l'ingestion de produits caustiques. Medecine et Chirurgie Digestives. 1993 ; 22 :91-3.

[10] Cowan T, Foster R, Isbister GK. Acute esophageal injury and strictures following corrosive ingestions in a 27-year cohort

Am.J.Emerg.Med. 2017;35:488-92.

[11] Havanond $C$. Is there a difference between the management of grade $2 b$ and 3 corrosive gastric injuries? J.Med.Assoc.Thai.2002; 85:340-44.

[12] Mamede RCM, Mello Filho FV de. Ingestion of caustic substances and its complications. Sao.Paulo.Med.J. 2001; 119:10-15.

[13] Osman M, Russell J, Shukla D, Moghadam falahi M, Granger DN. Responses of the murine esophageal microcirculation to acute exposure to alkali, acid, or hypochlorite. Journal of pediatric surgery. 2008; 43:1672-78.

[14] Contini S, Scarpignato C. Caustic injury of the upper gastrointestinal tract: a comprehensive review. World.J.Gastroenterol. 2013; 19:3918-30.

[15] Zargar SA, Kochhar R, Mehta S, Mehta SK. The role of fiberoptic endoscopy in the management of corrosive ingestion and modified endoscopic classification of burns. Gastrointestinal endoscopy. $1991 ; 37: 165-69$.

[16] Cheng H-T, Cheng C-L, Lin C-H, Tang J-H, Chu Y-Y, Liu N-J, et al. Caustic ingestion in adults: the role of endoscopic classification in predicting outcome. BMC gastroenterol. 2008; 8:31.

[17] Bahrami-Motlagh H, Hadizadeh-Neisanghalb M, Peyvandi H. Diagnostic accuracy of computed tomography scan in detection of Upper gastrointestinal tract injuries following caustic ingestion. Emerg. $2017 ; 5:$ e61.

[18] Bruzzi M, Chirica M, Resche-Rigon M, Corte H, Voron T, Sarfati E, et al. Emergency computed tomography predicts caustic esophageal stricture formation. Ann.surg. 2019; 270:109-14.

[19] Chirica M, Bonavina L, Kelly MD, Sarfati E, Cattan P. Caustic ingestion. The Lancet. 2017; 389:2041-52.

[20] Casasnovas AB, Martinez EE, Cives RV, Jeremias AV, Sierra RT, Cadranel $\mathrm{S}$. A retrospective analysis of ingestion of caustic substances by children. Tenyear statistics in Galicia. Eur.J.Pediatr.Surg. 1997;156:410-14. 